\title{
Why has sustainability advanced in management schools? A sociological explanation
}

\section{Abstract}

Bruno de Souza Lessa ${ }^{1}$

http://orcid.org/0000-0002-1696-394X

Ana Clara Aparecida Alves de Souza ${ }^{1}$

http://orcid.org/0000-0001-5574-2560

Fernando Dias Lopes ${ }^{1}$

http://orcid.org/0000-0003-0037-0135

This theoretical essay aims to provide a sociological explanation for the increasing importance of sustainability principles and practices in Management Schools. It does so by approximating two theoretical perspectives. First, from a macrosociological standpoint, it employs some of Pierre Bourdieu's core concepts and his theory of the State to interpret how sustainability-related principles and practices have advanced in Management Schools, theorizing about the context of developed countries. Second, it changes the focus onto a microsociological perspective to analyze how these advances have been taking place in Brazil. In order to do so, it utilizes Bernard Lahire's conceptual apparatus and his sociology at an individual scale. Therefore, this essay supports a double-folded argument. On the one hand, it claims that in developed countries the State has been the protagonist for the advancement of sustainability in Management Schools, since the State has the power over monopolies that are fundamental to engender social changes at national level. On the other hand, when its focus is shifted onto Brazilian reality, it argues that the State has a smaller participation regarding the advancements of sustainability-related practices and principles in Management Schools. Thus, the essay claims it is necessary to change the focus to the importance of key individuals, who have been essential for such advances.

\section{Keywords}

Sustainability - Management schools - Management schools in Brazil - Pierre Bourdieu - Bernard Lahire.

1- Universidade Federal do Rio Grande do Sul. Porto Alegre, Rio Grande do Sul - Brazil. Contacts: brunolessa85@yahoo.com.br; clara.ufc@gmail.com; ; fernando.lopes@ufrgs.br.

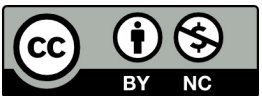




\section{Por que a Sustentabilidade tem avançado nas Escolas de Gestão? Uma explicação sociológica}

\section{Resumo}

Este ensaio teórico tem como objetivo fornecer uma explicação sociológica para a crescente importância dos princípios e práticas da Sustentabilidade nas Escolas de Gestão. Para isso, aproxima duas perspectivas teóricas. Primeiro, sob um ponto de vista macrossociológico, emprega alguns conceitos centrais de Pierre Bourdieu e sua teoria do Estado para interpretar como os princípios e práticas relacionados à Sustentabilidade têm avançado nas Escolas de Gestão, teorizando a partir do contexto de países desenvolvidos. Segundo, muda-se o foco para uma perspectiva microssociológica para analisar como esses avanços têm ocorrido no Brasil. Nesse sentido, utiliza o aparato conceitual de Bernard Lahire e sua sociologia em escala individual. Sendo assim, este ensaio defende um duplo argumento. Por um lado, sustenta que em paises desenvolvidos o Estado tem sido o protagonista para os avanços da Sustentabilidade nas Escolas de Gestão, pois é o Estado que possui os monopólios fundamentais para engendrar mudanças sociais em um nível nacional. Por outro lado, quando se volta para a realidade brasileira, argumenta que o Estado passa a ter uma participação menor nos avanços dos princípios e práticas relacionados à Sustentabilidade. Defende-se que se faz necessário mudar o foco para a importância de individuos-chave, que têm sido essenciais para tais avanços.

\section{Palavras-chave}

Sustentabilidade - Escolas de gestão - Escolas de gestão no Brasil - Pierre Bourdieu Bernard Lahire.

\section{Introduction}

Over the past decades, the problems that have increasingly been caused by the impacts of human economic activities gave rise to sustainability as a prominent topic of discussion in society. Such movement is concomitant to the space of debates concerning the issue in different spheres of the social world, for example, in the realm of private companies, public organizations and NGOs. If a world more oriented to the principles of sustainability, namely, the balance between economic profits, social responsibility and environmental protection (ELKINGTON, 1998) is to be consolidated, a different type of education also needs to be considered so that new socialization processes may engender another kind of societal configuration.

Moreover, sustainability has also been growing in importance as a subject of research and teaching in different levels of the schooling system. Not ignoring its relevance in other educational levels, many authors believe that sustainability has great 
importance in higher education, especially in Management Schools, since they are in charge of socializing, training and educating future managers. These individuals have fundamental social importance due to their key role in both private and public organizations (SODERBAUM, 1999; MURTAZA, 2011; STUBBS; COCKLIN, 2008; SODERBAUM, 2009; JACOBI; RAUFFTLET; ARRUDA, 2011; PALMA, 2015; FIGUEIRO, 2015; SCHUTEL, 2015; BRUNSTEIN et al., 2015; TIANA et al., 2017).

Thus, the aim of this theoretical essay is to describe, through sociological theoretical lenses, the advances of sustainability that have been taking place in Management Schools both in developed countries and in Brazil. In this regard, we present a doublefolded argument. First, considering the developed contexts, we draw on epistemological contributions of Pierre Bourdieu to argue about the role of the State for moving forward with sustainability. Second, by using concepts from Bernard Lahire's sociology, we disclose the importance of individual actors in the Brazilian scenario where the State plays a less prominent role as a social enabler.

Our main objective is to provide a concise and objective sociological explanation for these phenomena and their double instance. To do so, we argue that Pierre Bourdieu's analysis of the State (1991, 1996, 2007, 2014), and the way its presence affects society in different levels, are vital to understand the broad societal mechanisms that have been allowing sustainability to progress in Management Schools. Nevertheless, in the Brazilian context, wherein the State does not appear as the main promoter of sustainability, we found in Bernard Lahire's (2004, 2005, 2012, 2014, 2015) studies about individuals and their role in society a more reliable explanation to comprehend how the issue has been gaining momentum. By approximating these two theoretical apparatus, we intend to conciliate the macro and microsociological levels of these phenomena.

In other words, on the one hand, we argue that in developed nations the State and its operational institutions have been operating as the most protagonistic agents for sustainability in Management Schools. This phenomenon occurs because of its power within the social world, insofar as the State holds the monopoly over taxation as well as over physical and symbolic violence. On the other hand, this Bourdieusian explication does not fit into the Brazilian case once the State does not perform the same role in this country. In Brazil, we theorize and propose, drawing on Bernard Lahire's conceptual apparatus, that it is the prominence of certain individuals, their stock of dispositions and their concentration of symbolic power, which allow the development a sustainability-oriented agenda.

Regardless of the theoretical purposes of this text, we do not intend to discuss the concepts from an extensive epistemological perspective. This essay positions itself in the field of Applied Social Sciences, therefore, it goes beyond sociological theorization; it focuses on applying the conceptual apparatus on empirical social phenomena. In addition, it is not our aim to debate in detail neither the principles or practices of sustainability nor the ones of Management, but to use sociological theories to comprehend how these two areas have been interacting with one another, taking a specific part of the schooling system as the locus of analysis. In this perspective, we draw on ideas put forward by Bourdieu and Passeron (1992), who consider the formal schooling system as the major operational mechanism used to crystallize norms and values in a specific society. 
Therefore, in order to reach these objectives and defend such argument, this essay is divided into six sections. After this introduction, the second section outlines concisely and in operational terms the general reasons for the advancement of sustainability in the social world and, as a consequence, in Management Schools as well. Later, the third section describes the role of the State for such advances in developed countries by employing Pierre Bourdieu's epistemology. The fourth section outlines how the influence of the State shifts onto individuals, working with more specific Bourdieusian concepts. Afterwards, the fifth section stresses the relevance of individuals for the Brazilian context by using Bernard Lahire's conceptual apparatus. In the concluding section, we finish by presenting the final remarks about our argument.

\section{Why has sustainability advanced in the social world?}

The objective of this first section is to argue that the advances foregrounded in previous studies are based on an array of historical transformations, which, in their turn, enabled the emergence of sustainability as a central topic for teaching in Management Schools. As Norbert Elias (1994) sustains, it is necessary to understand societies as a series of interdependent networks in constant reconfiguration. Social formations are not static, hence they need to be understood within their inherent complexity.

In this sense, studies focusing on developed countries such as Canada, England, the USA, Germany and Australia evidenced certain "triggers" that can be regarded as central elements if we want to grasp the rise of sustainability. Considering our argument and the aims of this essay, we do not intend to make an in-depth elaboration of these triggers, which are, in fact, a set of possible reasons. Nevertheless, these reasons must be understood not in the sense of a causal nexus, but as a heuristic strategy to comprehend the social phenomenon (SODERBAUM, 1999; MURTAZA, 2011; STUBBS; COCKLIN, 2008; SODERBAUM, 2009; JACOBI; RAUFFTLET; ARRUDA, 2011; PALMA, 2015; FIGUEIRO, 2015; SCHUTEL, 2015; BRUNSTEIN et al., 2015).

First, the transformations the literature brings forward highlight the importance of systematic economic crises as well as the burgeoning shortage of resources. These two factors have been central to confront the rationality of neoclassical economics. Since the end of the Second World War, but more intensively during the 70s, it has become increasingly difficult to maintain the model of doing businesses following such rationality, which gives centrality to an exponential profit maximization enacted by an ideal model of a self-interested individual (PALMA, 2015; FIGUEIRO, 2015; SCHUTEL, 2015; BRUNSTEIN et al., 2015).

Second, other players, such as China and India, have emerged at world level with great power of negotiation. Their enormous capacities for production and consumption have caused deep changes in the world both in economic and in environmental terms. In this regard, it has not been possible for developed countries to ignore their economic power and their capacity to affect the natural environment (SODERBAUM, 1999; MURTAZA, 2011; STUBBS; COCKLIN, 2008; SODERBAUM, 2009; JACOBI; RAUFFTLET; ARRUDA, 2011). 
Third, these objective social transformations have brought about the rise and diffusion of sustainability-oriented practices as a way to ensure continuous development. Nonetheless, this development would not be termed in a one-dimensional perspective, that is, instead of thinking only in terms of economic growth, new forms of development would take into consideration socially responsible as well as environmentally respectful strategies to produce, trade and consume services and goods as well as entire novel alternatives of living. It is necessary to assert that the agendas related to sustainability had been first engendered by civil society organizations and only later they were incorporated by and through the State (SODERBAUM, 1999; MURTAZA, 2011; STUBBS; COCKLIN, 2008; SODERBAUM, 2009; JACOBI; RAUFFTLET; ARRUDA, 2011; PALMA, 2015; FIGUEIRO, 2015; SCHUTEL, 2015; BRUNSTEIN et al., 2015; TIANA et al., 2017).

For the sake of the argument and objectives of our essay, we deem the formal schooling system as the main operational mechanism employed to push these agendas back into society. In addition, once managerial education is a central concern in this scenario, Management Schools have become an integrating part of sustainabilityrelated policies.

Therefore, in order to provide the underpinning to apprehend the importance of the State, we draw on the Bourdieusian theoretical explanation to unveil the underlying structures enabling it to exercise its role. Our explanation follows two movements. The first one presents Pierre Bourdieu's conception of State and describes its social functions. Afterwards, the second movement expands this initial conceptualization and description using Bourdieu's terminologies to connect State and individuals as well as their impacts on Management Schools.

\section{The State and its importance}

In this first movement, Bourdieu integrates and reformulates two classic (and self-complementing) definitions of the State, i.e., the ones provided by the German sociologists Max Weber and Norbert Elias. For Weber, on the one hand, the State is defined as the holder of the legitimate monopoly over physical violence. The possession of this monopoly grants the maintenance of internal relations of power and domination that are inherently constitutive of the most diverse social actions. In the aggregated, these actions would compose the social fabric of meanings shared by all social agents, an element that would confer cohesion to what we call society (BOURDIEU, 1989, 1991, 2014).

For Elias, on the other hand, for the State to ensure this first monopoly, it would be also necessary to guarantee a second one, namely, the monopoly over taxation. Elias (1994) argues that insofar as the State builds a rational, legal and bureaucratic apparatus to maintain the first monopoly, it also becomes vital to hold the power over tax collection on a determined territory. Recursively, the second monopoly is vital to finance the first one. Therefore, these two monopolies are mutually dependent.

Bourdieu (2014) takes into consideration these two perspectives and adds to them a third one, that is, the State also defines itself by the possession of the monopoly over 
symbolic violence. The State is the only social agent with enough power to legitimize certain cultural arbitrariness, which, in its turn, would be considered the true schemes of perception, evaluation and action by all other social agents. These schemes would not be "natural" in the sense of possessing a biological origin. They would stem directly from the dominant social classes, since they are the ones that rule over the State and, therefore, have the power to determine its agenda.

For the French sociologist, in effect, the State has the power to engender social structures that have a double existence. Initially, they present themselves objectively as a first order constituted by hierarchical positions distributed in society. Secondly, these social structures appear as a subjective order in the sense of schemes of classifications, i.e., bundles of subjective dispositions and cognitive models that outline the forms of thinking, feeling and acting in the social world. Social divisions, for instance, are inscribed both in the material order of distinctive and hierarchical distributions as well as in the symbolic order of practical classifications (BOURDIEU, 1989, 1991, 2014; LOYAL, 2017).

Bourdieu (2014) states that the State brings together these objective and subjective instances through its different institutions. In this regard, schools, public services and welfare organizations would need to be in consonance to give shape and constitute social identities as well as all other forms of thinking. Through these institutions, those people who control the State ensure the power to administer and model the lives of the ones who are in its territorial boundaries.

As a result of these aspects, the State emerges as the protagonist of the advancements observed in developed countries because it holds the power to force and articulate social pressures in objective terms. According to Bourdieu (2014), the State employs its monopolistic power to influence the configuration of all social fields as well as to guide their dynamics.

For example, only the State would have the power to determine which curriculum parameters Management Schools would follow compulsorily, compelling these organizations to comply with specific social demands such as the ones related to sustainability. The State would guarantee not only the adoption and implementation of curricula, but also their continuity within a determined structure. In Bourdieusian terms (BOURDIEU; PASSERON, 1992), this compliance would be oriented to the reproduction of a new cultural arbitrariness, namely, the one concerned with sustainability principles to be inculcated via the formal school system in the agents overlapped in society.

Furthermore, the implementation of sustainability-related policies in different realms of the social world, besides the formal schooling systems, reinforces the contextual transformations previously mentioned. In this sense, Palma (2015), Figueiró (2015) and Schutel's (2015) PhD theses performed extensive researches into American, Canadian and English Management Schools' curricula, showing that structural transformations in society were essential for the emergence of new curricula underpinned by integrating and holistic visions of sustainability. In spite of the initial role of organizations from civil society, the State was essential for this phenomenon. 


\section{The State inside and outside individuals: habitus, doxa and} illusio

Before exploring certain central Bourdieusian concepts, it is imperative to recall that due to the argument we support and to our objective, it is not our focus to provide a detailed description of these terms nor is it our intention to provide a genealogy about any of these concepts. Previous studies have already supplied rich substantive contributions in this direction (e.g. BOURDIEU, 1996, 2004; WACQUANT, 2007; PETERS, 2010, 2013; CAETANO, 2011, 2012).

In this regard, we draw on the ideas presented by Wacquant (2018), who suggested that if one is willing to work with the Bourdieusian epistemology, he or she is not obliged to draw on the conceptual apparatus in its entirety. Bourdieu's concepts are historical and dynamic in their very essence, therefore they need to be constantly confronted with contemporary empirical problems in order to be reexamined and reevaluated. By doing so, one does not only contribute with the development of Bourdieu's epistemology itself, but also helps other scholars to envisage possible uses for the terms in different contexts.

In view of our argument, we first provide a brief definition about each concept followed by their operational use; our goal is to explain how the State affects the social world and the individuals within it. In other words, our aim is to adopt the concepts as analytical instruments to outline how the State has been crucial for sustainability to become a consolidated topic of debate in Management Schools.

The influence of the State in the social world and in the relations established within it leads to the formation of what Pierre Bourdieu named different habituses. In definitional terms, the habitus is a set of mental schemes oriented to specific norms and values related, in their turn, to specific social fields. The habitus can be outlined as a generative matrix of practices, i.e., schemes of perception, classification and action that holds correspondence with a determined social field (BOURDIEU, 1977, 2007; BOURDIEU; WACQUANT, 1992).

A field is a social space in which agents occupy positions determined by the volume and structure of the capitals they possess as well as by their habitus. The position of each particular agent is a product, in its turn, of the interaction between the specific rules of the field, the agent's habitus and agent's capitals. Furthermore, fields interact with one another, and are divided hierarchically in the sense that all fields are subordinated to the larger field of power and class relations (BOURDIEU, 2004a, 2004b).

In tune with Marx, Bourdieu (1985) defines capital as accumulated efforts that might be privately appropriated by an agent or a group, providing these individuals with "social energy". Nonetheless, the French sociologist moves on with the Marxian proposal. He agrees with the idea that capital is a socially recognized source of power, but this power portrays itself through different ways in society (BOURDIEU, 1985).

For instance, the constant socialization processes in the field of Management lead individuals (or "agents", in Bourdieusian terms) to acquire a habitus correspondent to the structure of this field. If the field values certain kinds of knowledge, for example, the neoclassic economic rationality, the agents in the field tend to have a habitus underpinned 
by characteristics of such rationality. In effect, these individuals are likely to value certain kinds of knowledge in detriment of others.

Nevertheless, the habitus, the social fields and their inner relations are dynamic, thus, inasmuch as changes are a constant in the social world, these structures also change and schemes that used to be taken for granted or, at least as more legitimate during a determined period, might be gradually considered retrograde or anachronistic in another temporality (BOURDIEU, 1996).

In other words, as the world with its pressures and demands around us changes, we change as well. This explains, roughly speaking, why social transformations engendered over the past decades have modified not only the field of Management, but also Management Schools' structures in different ways and levels in developed countries. Furthermore, the kinds of knowledge that used to rule solely in the mainstream thought have started to be questioned by other sorts of knowledge and this dispute, mediated by the State and its actions, also help in modifying the habitus, the social fields and their aforementioned dynamics.

In this perspective, the State also demonstrates its presence and influence by endowing certain individuals with titles and diplomas, which, in their turn, enable these agents to perform specific hierarchical roles of power. These individuals are, for instance, the specialists or renowned professors who hold positions recognized by society as a whole insofar as they had been granted firstly by the State (BOURDIEU, 2014; LOYAL, 2017). These agents are vital for the production and reproduction of the Management field's related habitus as well for the field itself, for instance.

Furthermore, professors and specialists would retain networks of contacts with others of their kind who turn out possessing habituses similar to theirs. These networks might be mobilized, e.g., to give scale to their influence not only in the Management Schools they work for, but also in the managerial field as a whole. The State's presence appears implicitly and explicitly given its fundamental importance as the being that monopolizes both the power to endow as well as to maintain titles and diplomas (BOURDIEU, 2014; LOYAL, 2017).

Therefore, if one happens to investigate the changes engendered by sustainabilityrelated issues in the field of Management, he or she realizes that these transformations are consolidated in agents' habituses. In addition, by employing Bourdieu's epistemology, it becomes necessary to highlight two other processes that are essential for the crystallization of any transformation in the social world, namely, the change in the illusio, and, finally, in the doxa. These elements are also crucial to understand the structuration of any given field as well as their related dynamic constituents.

The illusio would be, in broad terms, the motivation that makes agents want to participate in the managerial field, which would include economic concerns as well as socioenvironmental concerns typical of contemporary social relations. In this regard, as an agent enters the field and aligns with its illusio, he or she also needs to accept its external and internal interests, imposed by the specific social rules legislating over each field (BOURDIEU, 2004a, 2004b). 
Following this perspective, as anyone enters the field of Management, which also tends to happen through Management Schools, he or she will be required to align with some specific set of expertise and concerns regarded as more or less legitimate. As sustainability rises in importance, newcomers gradually need to learn more about it, thus, learning about and recognizing its social legitimacy. Finally, the transformation in the illusio leads, in addition to the other elements previously mentioned, to an even deeper transformation that takes place in what is deemed as absolutely taken for granted in the field, i.e., its doxa.

In this perspective, the doxa must be understood as the experience of a completely stabilized social order, in which power relations are found to be naturalized and unquestioned in such a way that all social arrangements are entirely taken for granted. This phenomenon happens because every established order tends to produce the naturalization of its arbitrariness (BOURDIEU, 1977). The gradual change of the doxa has been a vital step when we consider the progressive consolidation of sustainability in Management Schools.

This progressive transformation takes place as, for instance, the supporters of a new rationality break with the old doxa (e.g. profit maximizing and self-interested) and show its limits, they push concomitantly into the field a new doxa (e.g. socially responsible and environmentally respectful) capable of modifying the dynamics of the field. By putting their demands and pressures through State's institutions, these supporters grant themselves enough power to modify all the previously cited elements, but more importantly, the doxa itself (BOURDIEU, 2004a).

Considering all the aforementioned aspects, the international advances of sustainability in Management Schools have been a product of interactive relational changes in the socioenvironmental context, in the objective material structures of the social world and in the subjective schemes within individuals. These dynamic elements have been influenced directly and indirectly by the presence of the State, which holds the power to act in the restructuration of the educational system, turning out to transform gradually the agents' habituses. The State is the only entity with possession of the monopolies necessary to influence the interaction of these instances since it is, at the same time, the means through which these interactions take place and mediator of the struggles occurring in the social world.

In spite of this relational perspective established between the State and individuals in Bourdieu's sociology, it is clear that the former has greater importance over the actions of the latter. In this regard, it is helpful to provide a further sociological theorization about the role of the individuals because, as we examine the advances of sustainability in Management Schools in Brazil, we find out that the State's importance diminishes whereas the relevance of certain individuals expands.

Palma (2015), Figueiró (2015) and Schutel's (2015) PhD theses corroborate this observation as they evidenced, by comparing English, Canadian and American contexts with the Brazilian one, that the role of certain key individuals in Management Schools in Brazil has been much more relevant for changes. These authors highlighted that in the developed countries studied the State and its pressures were fundamental, whereas in 
Brazil changes towards sustainability perceived in Management Schools had been mostly carried out by certain faculty members with a particular orientation.

Therefore, due to this emerging necessity, namely, to comprehend individuals' role in the Brazilian context, the next section brings forward some key concepts from Bernard Lahire's sociology, which are very helpful to explain and understand this phenomenon nationally.

\section{The role of individuals in the advances of sustainability in Brazil}

In order to preserve the centrality of our argument and to keep its clarity, we decided not to develop another argument about the pressure exerted by foreign States over the field of Management Schools in Brazil. Nonetheless, in this regard, it is necessary to highlight that any science as well as its teaching cannot be taken as practices taking place among only a community of native individuals (BOURDIEU, 2004a). These practices are intertwined by forces and pressures coming from institutions from more developed countries which, in their turn, influence scientific and educational practices in the countries of the periphery such as Brazil.

Although it has not been scrutinized here, we would like to concede to the fact that changes in the curricula of Brazilian Management Schools might also be a reverberation of transformations coming from more prestigious foreign ones. Furthermore, intellectuals from developed countries turn out influencing research interests and world visions from their peers based on peripheral countries like ours. Insofar as the latter seek consecration and to accrue symbolic capital in their native field, they are likely to emulate what is the mainstream proposed by the former (BOURDIEU, 2004b). In other words, Brazilian notorious intellectuals are a part of an interdependent community in which, to accumulate prestige, it becomes necessary, to some extent, to mirror certain practices from abroad.

Nonetheless, based both on Bourdieu and Lahire's sociological tenets, it is important to bring forth that individuals do have a certain degree of agential power on the fields in which they participate. Even though these fields exert pressure on individuals, they are able to make decisions underpinned by their heterogenous social trajectories in the social structure.

Therefore, we would like to focus on Lahire's sociology to argue that the inclination intellectuals related to sustainability in Brazil cannot be regarded only as a result of foreign pressures. These individuals were socialized in plural contexts, hence, they acquired plural sets of dispositions and some of these dispositions are stronger or weaker than others (LAHIRE, 2002). Thus, we argue that the transference of stronger dispositions connected with sustainability practices and principles have also been a key element for the prominence of the work these notorious intellectuals for the advancement of sustainability in Management Schools. In more objective terms, it is not only a matter of external foreign (and field) pressures, but also an issue related to dispositional inclinations and choices.

Therefore, in order to theorize about the importance of specific individuals for the advancements of sustainability in Brazilian Management Schools, it is imperative to alter 
the scale of analysis. If from an international macrosociological perspective the State has been of fundamental importance, we argue that in Brazil such advancements have been performed mostly by the actions of prominent individuals. Hence, it is necessary to employ a microsociological theoretical apparatus to understand why specific social agents have pushed sustainability-related agendas into Management Schools.

Our theoretical proposition starts by affirming, drawing on the ideas of Bernard Lahire (2002), that the existing habitus in social agents in the field of Management cannot be considered a homogenous matrix, but rather a stock of dispositions enabling the recognition of sustainability principles as more legitimate. In this regard, also in tune with Bourdieu (1985), such principles and their related practices are the kind of knowledge valued by determined individuals instead of others connected with neoclassical economics, for example.

By approximating Bourdieu and Lahire's sociologies, we can understand practical mental dispositions (the habitus) not only as a product of categories retraceable to family socialization, or emerging from the continuous exercise of a profession, but also as a product of both processes. Moreover, these two sociologies together enable us to take into account the most diverse socializing experiences that people undergo in their biographical trajectories.

More specifically, in alignment with Lahire (2002, 2006), we argue that professors in Management Schools in Brazil have their habituses connected with social norms that were produced, sustained and diffused through idiosyncratic kinds of interactions during their social lives. Over time, these processes constituted dialectically the beliefs and practices that are reinforced (or not) by personal experiences. The interactions with other people and institutions have the power to intensify the incorporation of dispositions linked with specific sets of norms. A disposition has its strength proportional to how much it was actualized, i.e., to the frequency the agent underwent situations reinforcing it.

Following this logic, it possible to theorize that the increasingly number of disciplines and courses involving sustainability in Management Schools has great power over individuals' habituses. This happens because these experiences intensify the socializing frequency they are exposed to sustainability's principles and practices. Later, as these individuals occupy strategic positions in Management Schools, they promote these normative standards through other socializing processes. In this sense, long-lasting mentalities are not incorporated in a few hours, but through continuous and systematic processes.

If the principles underlying such socializing processes are sufficiently coherent, they are likely to unify students and professors' dispositions in a way that introduces a different social cohesion to the field (BOURDIEU, 2004a, 2004b; LAHIRE, 2005, 2006). Insofar as students experience the most diverse sort of courses or disciplines, but all linked through sustainability-related principles, they will acquire (or reinforce) dispositions connected with these principles. The earlier these experiences happen in Management schools, the more the related dispositions are crystallized in their habituses.

Lahire (2004) emphasizes the importance of the ontological convergence between the habitus and the contexts developed over time. Moreover, by changing the focus of analysis onto individuals, Lahire (2015) considers all the realms of practices and draws our attention to the mixture of favorable and unfavorable conditions that make agents' dispositions stronger 
or weaker. Analogously, this process also underlies the advancements of sustainability because both professors and students have their stocks of dispositions built upon common situations, which end up creating a shared intersubjectivity among all the agents involved in the field. This common intersubjectivity is another element that exerts enough pressure on any given field and gradually transforms what is regarded as legitimate in it.

By paying attention to the way professors and other specialists were socialized, we can comprehend how aligned their stocks of dispositions are with the main cultural arbitrariness operating over the field of Management. The legitimacy of a cultural arbitrariness is connected with issues from the objective world and operates as an imperative on individuals' dispositions (LAHIRE, 2005, 2006).

Considering the Brazilian context, this theoretical perspective is very prolific for two reasons. First, it explains how perceptions about what is relevant are transferred from one individual to another in Management Schools. Second, it further demonstrates the centrality of a person's hierarchical professional position in his or her ability to influence a specific field. Thus, the Lahirean epistemology helps us to comprehend why a particular piece of knowledge becomes more important than another by highlighting individuals rather than the State and its institutions.

Therefore, the analysis based on Lahirean epistemology provides us not only with the theorization about advancements in Brazil, but also with the production of future hypotheses about objective and subjective changes. Furthermore, it can unveil alternatives to a determined status quo in the mainstream of what is taught in Management Schools. In this regard, the sociological study of individuals might be as fruitful as the Bourdieusian macrosociological perspective.

\section{Final remarks}

This theoretical essay aimed to debate how sustainability has been advancing in Schools of Management both in developed nations and in Brazil. Deeming Sustainability as the ideal balance between economic development, social responsibility as well as respect towards the environment, we put forward a double-folded argument that was sustained on Pierre Bourdieu and Bernard Lahire's sociologies.

First, drawing on Bourdieu's macrosociological perspective, we argued that advances seen in determined developed nations are the result of actions devised by the State, which meant that its monopoly over symbolic violence was essential in these developed contexts. It would not be possible for any other social actor to implement changes in the magnitude necessary to modify Management Schools' curricula. Only the State and its high concentration of symbolic power could ensure the implementation and continuity of sustainability-oriented policies. From a Bourdieusian perspective, civil society organizations could even exert, for instance, considerable social pressure, but only the State would be able to deploy effective actions over other instances of society.

Second, regarding a microsociological perspective, we relied on Bernard Lahire's sociology of individuals to argue that in Brazil it would be necessary to focus not on State's actions, but on the protagonism of determined individuals in Management Schools. Hence, 
their protagonistic role is the fundamental enabling element for Sustainability in Brazilian Management Schools. The practices of these protagonists could be explained, broadly speaking, by taking into account the fact they have mental (and practical) dispositions oriented to recognize sustainability principles as more legitimate, thus, to be taken forward within the Management structure of higher education institutions, for example.

Therefore, this essay contributes in two directions. First, it fuels the debate about the importance of sustainability by integrating macro and microsociological perspectives. The approximation of Bourdieu and Lahire's purposes enables us to unveil, in a concise and cohesive theoretical perspective, the operational mechanisms underlying the advancements witnessed both in developed countries and in Brazil. Second, it brought two analytical tools that could also be employed in empirical research. Future studies could focus, for instance, on scrutinizing not only broader institutional contexts, but also individual trajectories to understand how other relevant issues have been evolving over time.

Accordingly, we offered an epistemological alternative that emphasizes the role of the State and its institutions, given that their construction is concomitant to the emergence of a common historical transcendence, which appears as if it was immanent to everyone in a field (or even in society). We agree with Bourdieu (1989, 1991, 1996, 2014) that by ruling over the implementation of the most various practices, the State imposes and inculcates categories of perception, modes of thinking as well as other mental structures imbricated with hegemonic forms of classification. Furthermore, the kind of analysis promoted here is rather advantageous once it also considers the complexity of individuals' experiences and their multi-layered structure of dispositions.

As suggestions for future research, further studies could lean on the impacts of the United Nations' Objectives for Sustainable Development in Management Schools, examining, for instance, whether or not these Objectives reverberate in the way sustainability has been implemented or taught. Moreover, future studies could employ quantitative methods to provide empirical evidence about the advances (or halts) in the progress of sustainability in these Schools. Because of the theoretical and exploratory nature of this work, it would not appropriate to approach these topics since they would unavoidably result in the mischaracterization of this text, weakening its argument and focus. Nevertheless, future research could yield excellent results if these topics were developed properly.

Furthermore, another path to be explored could be the role of foreign pressures in the field of Management Schools, and quantitative methods could be employed to investigate such influence. Future research could also be qualitative and scrutinize the influence of theories and scientists coming from developed countries on Brazilian intellectuals. By investigating the latter's social trajectories it would be possible, for example, to settle their stocks of dispositions, to compare the influence from abroad with their previous socializations, to confront one with the other and trace the width of external pressures versus their internal dispositions. Also due to limitations of space, these discussions could not be developed in this article.

Finally, if sustainability is to be investigated as a social phenomenon, this will require an apparatus from social theories to disclose its inner structures and enable the 
comprehension of its internal logic. Sustainability cannot be understood as the final solution for contemporary society's problems because such understanding is unrealistic and unscientific. Sustainability is of much greater contribution for both the academia and for civil society, if it is understood as a present manifestation of the transformations in capitalism. In this sense, from a scientific standpoint, to apprehend a phenomenon in its essence is vital to understand its totality. To do so, it is also imperative to discern its mechanisms, and sociological theorization has proven to be indispensable for such an enterprise.

\section{References}

BOURDIEU, Pierre. A distinção: crítica social do julgamento. São Paulo: Edusp; Porto Alegre: Zouk, 2007.

BOURDIEU, Pierre. Espíritos do estado: a gênese do campo burocrático. Actes de la Recherche en Sciences Sociales, Paris, v. 96, n. 96-97, p. 49-62, 1993.

BOURDIEU, Pierre. Language and symbolic power. Cambridge: Harvard University Press, 1991.

BOURDIEU, Pierre. 0 poder simbólico. Rio de Janeiro: Difel; 1989.

BOURDIEU, Pierre. Os usos sociais da ciência: por uma sociologia clínica do campo científico. São Paulo: Unesp, 2004a.

BOURDIEU, Pierre. Outline of a theory of practice. Cambridge: Cambridge University Press, 1977.

BOURDIEU, Pierre. Razões práticas: sobre a teoria da ação. Campinas: Papirus, 1996.

BOURDIEU, Pierre. Science of science and reflexivity. London: Polity Press, 2004b.

BOURDIEU, Pierre. Sobre o estado: cursos no Collège de France (1989-1992). Tradução Rosa Freire d’Aguiar. São Paulo: Companhia das Letras, 2014.

BOURDIEU, Pierre. The forms of capital. In: RICHARDSON, John Greenwood. (Ed.). Handbook of theory and research for the sociology of education. New York: Greenwood. p. 241-258, 1985.

BOURDIEU, Pierre; PASSERON, Jean-Claude. A reprodução: elementos para uma teoria do sistema de ensino. Rio de Janeiro: Francisco Alves, 1970.

BOURDIEU, Pierre; WACQUANT, Loäc (Ed.). An invitation to reflexive sociology. Chicago: Chicago University Press, 1992.

BRUNSTEIN, Janette et al. Assessment and evaluation of higher education in business management: an analysis of a Brazilian case in the light of social learning theory for sustainability. Assessment \& Evaluation in Higher Education, London, v. 40, n. 6, p. 833-854, 2015. 
CAETANO, Ana. Para uma análise sociológica da reflexividade individual. Sociologia, Problemas e Práticas, Lisboa, n. 66, p. 157-174, 2011. Available on: <https://journals.openedition.org/spp/523>. Access on: Jan. 2018.

CAETANO, Ana. A análise da reflexividade individual no quadro de uma teoria disposicionalista. In: LOPES, João Teixeira (Org.), Registos do actor plural: Bernard Lahire na sociologia portuguesa. Porto: Afrontamento, 2012. p. 15-29.

ELIAS, Norbert. 0 processo civilizador: uma história dos costumes. Rio de Janeiro: Jorge Zahar, 1994.

FIGUEIRO, Paola Schmitt. Educação para a sustentabilidade em cursos de graduação em administração: proposta de uma estrutura analítica. 2015. 262 f. Tese (Doutorado em Administração) - Escola de Administração, Universidade Federal do Rio Grande do Sul, Porto Alegre, 2015.

JACOBI, Pedro Roberto; RAUFFLET, Emmanuel; ARRUDA, Michelle. Educação para a sustentabilidade nos cursos de Administração: reflexão sobre paradigmas e práticas. RAM, São Paulo, v. 12, n. 3, ed. esp., p. 21-50, maio/jun. 2011.

LAHIRE, Bernard. 0 homem plural: os determinantes da ação. Petrópolis: Vozes, 2002.

LAHIRE, Bernard. Retratos sociológicos: disposições e variações individuais. Porto Alegre: Artmed, 2004.

LAHIRE, Bernard. Patrimônios individuais de disposições: para uma sociologia à escala individual". Sociologia, Problemas e Práticas, Lisboa, v. 49, p. 11-42, 2005.

LAHIRE, Bernard. A cultura dos Indivíduos. São Paulo: Artmed, 2006.

LAHIRE, Bernard. A fabricação social dos indivíduos: quadros, modalidades, tempos e efeitos de socialização. Educação e Pesquisa, São Paulo, v.41, n. esp., p.1393-1404, 2015.

LOYAL, S. Bourdieu's theory of the state. London: Palgrave, 2017.

MURTAZA, Niaz. Pursuing self-interest or self-actualization? From capitalism to a steadystate, wisdom economy. Ecological Economics, Amsterdã, v. 70, n. 4, p. 577-584, 2011.

PALMA, Lisiane. Aprendizagem transformadora sustentável: integrando processos de ensino-aprendizagem, gestão e mudança para sustentabilidade nos cursos da área de gestão à luz da teoria da complexidade. 2015. 300 f. Tese (Doutorado em Administração) - Escola de Administração, Universidade Federal do Rio Grande do Sul, Porto Alegre, 2015.

PETERS, Gabriel. Humano, demasiado mundano: a teoria do habitus em retrospecto. Teoria \& Sociedade, Belo Horizonte, v. 18, n. 1. p 8-37, 2010.

PETERS, Gabriel. Habitus, reflexividade e neo-objetivismo na teoria da prática de Pierre Bourdieu. Revista Brasileira de Ciências Sociais, São Paulo, v. 28, n. 83, p. 47-71, Oct. 2013. 
SCHUTEL, Soraia. Aprendizagem transformadora para o desenvolvimento sustentável futuro: estudo de casos em cursos de administração no Canadá e no Brasil. 2015. 274 f. Tese (Doutorado em Administração) - Escola de Administração, Universidade Federal do Rio Grande do Sul, Porto Alegre, 2015.

SODERBAUM, Peter. Making actors, paradigms and ideologies visible in governance for sustainability. Sustainable Development, New Jersey, v. 17, n. 2, p.70-81, 2009.

SODERBAUM, Peter. Values, ideology and politics in ecological economics. Ecological Economics, Amsterdã, v. 28, n. 2, p.161-170, 1999.

STUBBS, Wendy; COCKLIN, Chris. Teaching sustainability to business students: shifting mindsets. International Journal of Sustainability in Higher Education, Bingley, v. 9, n. 3, p. 206-221, 2008.

TIANA, Sílvia Albareda et al. Barreras para la sostenibilidad integral em la universidade. Revista IberoAmericana de Educacion, Madrid, v. 73 n. 1, p. 253-272, 2017.

WACQUANT, Loäc. Esclarecer o Habitus. Educação \& Linguagem, Porto, v. 10, n. 16, p. 63-71, jul./dez, 2007.

WACQUANT, L. Four transversal principles for putting Bourdieu to work. Anthropological Theory, New York, v. 18, n. 1, p. 3-17, 2018.

Received on: July 5th, 2018.

Reviews on: October 29th, 2018. Approved on: November 27th, 2018.

Bruno de Souza Lessa is a Historian. He holds a master's degree in Management and Controllership by the Universidade Federal do Ceará (UFC). Currently, he is a PhD student in Management at the Universidade Federal do Rio Grande do Sul (UFRGS).

Ana Clara Aparecida Alves de Souza holds a master's degree in Management and controllership by the Universidade Federal do Ceará (UFC). She has a PhD in Manegement at the Universidade Federal do Rio Grande do Sul (UFRGS). Currently, she is a postdoctoral fellow at the Pontificia Universidade Católica do Rio Grande do Sul (PUCRS).

Fernando Dias Lopes is an Associate Professor I at the School of Management of the Universidade Federal do Rio Grande do Sul (UFRGS). Currently, he is connected to the Postgraduation Program in Management at UFRGS. 